\title{
DEVICES IMPACT ON THE CHILDERN: A SWOT ANALYSIS
}

\author{
Anna Sardiana ${ }^{1}$ \\ 'Indonesia Banking School, Jakarta, Indonesia \\ anna.sardiana@ibs.ac.id
}

Naskah diterima: 05 Nopember, 2020, direvisi: 15 Januari, 2021, diterbitkan: 31 Maret, 2021

\begin{abstract}
The digital revolution has changed the culture of communication and people's behavior to move to media quickly and easily through the use of devices. This has an impact on school children as part of the community of mobile device users. The purpose of this article is to explore the strengths, weaknesses, opportunities, and threats of using digital devices as well as their impact on school-age children. The method used in this research is a literature review (literature research), which is a study that studies and evaluates critically and deeply from the knowledge, ideas, and findings of previous studies. Research focuses on theories, laws, propositions, principles, or ideas that are used to conduct analyzes to solve the formulation of research problems. The data in this study were obtained from various of literature which were processed and analyzed using SWOT analysis (strength, weakness, opportunity, threat). The data analysis technique is descriptive argumentative. Conclusions are obtained after referring back to the formulation of the problem, the purpose of writing, and discussion. The results of the SWOT analysis in this study found that the use of devices in school children has positive and negative impacts and has opportunities and threats to watch out for.
\end{abstract}

Keywords: Devices; Smartphone; Gadget; SWOT analysis; Digital native

\section{Introduction}

The Information and telecommunications technology progress is so rapid that allows the application of new ways to be more efficient for the benefit and convenience of human life. This process do brings humans into the information age community whose dissemination is quite done through the internet. The development of the internet in the era of information technology has led to the creation of innovations in various fields. This is due to the ease factor that arises from the existence of the internet (Akmala, 2018).

In Indonesia, internet users showed a very high increase, from 88.1 million in 2014 to 132.7 million from a population of 256.2 million people, according to survey data from the Indonesian Internet Service Providers Association (APJII) in 2016 (Widiartanto, 2016). APJII also mentioned that if the majority of internet users came from the age group of 3544 years as much as $29.2 \%$ or around 38.7 million followed by the $25-34$ age group as much as $24.4 \%$ or around 32.3 million people.

The increase in internet usage has had an impact on the level of ownership and devices utilization in the world and especially Indonesia. Smartphone has a very important role of communication technology because it makes human life easier, more convenient, and changes in a person's mindset and even changes in human attitudes and character. This can be seen in the level of smartphone usage in Indonesia which reached 371.4 million users or 142 percent of the total population of 262 million people. That is, on average each resident 
uses 1.4 smartphones because one person sometimes uses 2-3 cards on several devices. While Indonesia's urban population reaches 55 percent of the total population. The following is an overview of mobile devices users in Indonesia in January 2017. (Katadata.com, 2018)

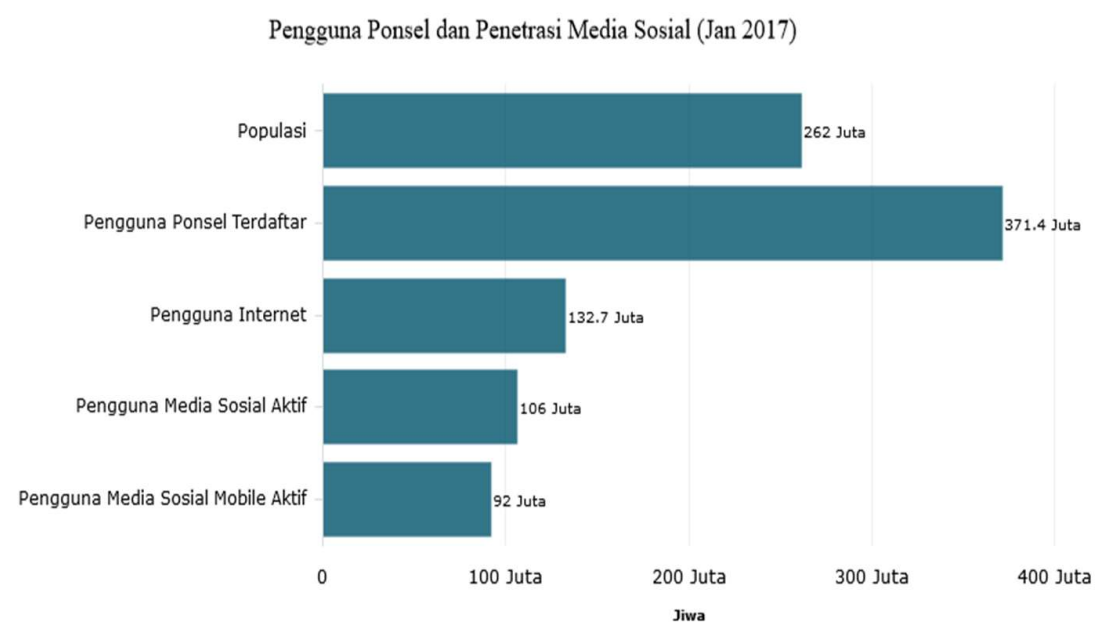

Graphic 1. Graphical Smartphone Users in Indonesia.

(Source: katadata.co.id, 2018)

Based on the graph above, compared to January 2016, mobile users in Indonesia increased by 14 percent. This shows that the penetration of mobilephone usage in Indonesia is always increasing. This is due to the use of devices not only in the domain of adults, but also for children.

In this 21 st century, children are confronted with the digital age, consequently children also use gadgets every day. The Digital Age is often referred to as new media, namely the change from mass media to the internet era. New Media Theory (Nurjanah, 2014) explains that "The description of the power of new media in influencing its new digital forms". In this digital age, everyone is easy to enjoy the ease of technological progress. It is not only parents and adults but also children and adolescents. Children and adolescents who incidentally are still students as skilled in using technology (Caraka \& Nindiya, 2017). Such children and adolescents are referred to as Generation Z. Generation $\mathrm{Z}$ themselves are children born around 1995 to 2010. Saragih (2012) explained that Generation $Z$ is a child who is very technologically literate or net generation. They prefer to interact with computers and communicate with online systems so they have a tendency not to meet their friends physically. Based on the results of a survey conducted by the daily news, Republika, one in three children even started using gadgets when they were three years old (Republika, 2014).

This shows that since they were toddlers, children of this century have been skilled in using devices. With tiny fingers, children can use devices ranging from playing games, taking photos, to surfing the virtual world. In fact, many parents feel they are inferior to their children when it comes to technology. (Fahrurozi and Sutrisno, 2018). Technological advances have great benefits in the lives of adolescents, especially to expedite the process of learning and communication. However, on the other hand adolescents also experience serious problems and dangers due to their childrens internet use (Barak, 2008). Excessive 
use of devices by children will have a serious impact on the lives of each child. So this study analyzes the impact of devices utilization on school children by using a SWOT analysis.

\section{Literature Review}

Today's generation is referred to as native digital generation. Digital Native (digital population) is a term for someone whose since their birth until they growing up, is inseparable from digital technology. This term was introduced by Marc Prensky in "Digital Natives, Digital Immigrants" (2001). Children and young people today are native to the digital world. They are surrounded every day by computers, smartphones and the internet. They take advantage of technological developments such as social media applications, blogs, vlogs, and so on. The issue raised by Prensky relates to the thinking of digital natives, among others: because digital natives receive abundant information very quickly, causing them to adapt differently from the previous generation. The digital native can do several jobs at once (multitasking). They prefer to see a representation of a phenomenon and then describe it with words and pictures. They tend to work randomly and prefer to work in teams. And they prefer a serious but relaxed atmosphere (Prensky, 2001).

As digital native, internet technology also impacts the behavior and lives of the present generation. Today's children are so familiar with the internet through various device devices, such as: computers, laptops, tablets, mobile phones, devices, and similar devices. Their lives start from; playing, communicating, socializing, channeling hobbies, and other aspects are inseparable from internet technology. (Chalim and Anwas, 2018)

Applications contained in the device such as game applications, ranging from adventure games, guessing to learning applications such as coloring applications, learning to read and write letters, cause early childhood children to be interested in the device. (Nizar et al 2017)

Facilitated by the ability of parents, the digital native is now very easy to have a smartphone or gadget in various forms such as computers or laptops, tablet PCs, and smart phones, namely electronic or mechanical devices with practical functions. One device that is commonly owned is a smart phone (device). Digital native is the most intensive generation of devices. According to Horringan (2000 in Roswita, 2015) there are two basic things that must be observed to determine the intensity: (1) frequency and (2) duration. Frequency is related to how often that person uses a device. Duration means how long the person is using a device. While Chaplin (2004 in Hagg, 2016) explains aspects of intensity including: (1) Frequency, (2) length of time, (3) full attention, and (4) emotional.

\section{Previous Research}

Kleinder Perkins Caufield \& Byers's Internet Trend report says that mobile users have an average of 150 cellphones a day. If accumulated, in one week the average person can use more than 1,050 devices (Gifary and Kurnia, 2015). Nielsen On Device Meter (ODM) research in February 2014 on the behavior of women who are more likely to spend more time using smartphones than men. It mentioned that Women can spend 43 minutes a day. In terms of age, gadget users are dominated by ages $20-22$ years. This age is a productive age and is referred to as digital native. Indeed, at this age people tend to look for entertainment and information from online media, one of which uses devices. (Gifary and Kurnia, 2015)

However, can the development of technology and easy access to information be used by these digital natives? The article that pulled out of the annual report of the Freshman Survey conducted by UCLA, during 2011 , only $38.1 \%$ of graduates had the average ability to operate computers. The report also found that only $3.2 \%$ were really serious about 
studying computer-related studies. The majority of the digital generation natively utilizes technology for fun and play. The same survey states that $94.8 \%$ of college graduates have always been online on Facebook or other social media since high school. The figure above is a general description of the phenomenon that the digital generation natively utilizes technology as playfulness. Although the younger generation is quite familiar with technology from birth, it does not mean they are very technology savvy. Instead they are considered not productive with technology, even do not understand how to navigate the application (Yunus. 2012)

How children and adolescents as digital natives relate to the education system and educators included in digital immigrants is certainly interesting to study. Students must certainly be able to take advantage of extrinsic and intrinsic advantages in order to achieve academic achievement. The clear intrinsic advantage he must have is achievement motivation. While extrinsic advantages that can be utilized is the mastery of Information Technology. So this research wants to explore the strengths, weaknesses, opportunities and threats of using devices by school students.

\section{Methods}

The method used in this research is literature review (literature research), which is a study that studies and evaluates critically and deeply from the knowledge, ideas and findings of previous studies (Wahono, 2016). Research focuses on theories, laws, propositions, principles or ideas that are used to conduct analyzes to solve the formulation of research problems. Previous research topics originated from articles in the form of national and international journals relating to the use of devices and the impact on their users.

The data used in the preparation of this paper comes from a variety of literary literature relating to the problem being studied. Some of the main types of references used are books, seminar papers, proceedings, journals, and scientific articles sourced from the internet. The types of data obtained are varied, both qualitative and quantitative.

Sources of data and information obtained from various literature and compiled based on the results of studies of information obtained. Writing efforts are interrelated with one another and in accordance with the topic being studied. The collected data is selected and sorted according to the topic of the study. Then the writing is done based on data that has been prepared logically and systematically. The data analysis technique is descriptive argumentative. Conclusions are obtained after referring back to the formulation of the problem, the purpose of writing, and discussion. The conclusions are drawn from the subject matter of the written work, and are supported with practical advice as further recommendations.

\section{Result and Discussion}

Smartphone or gadget is a device whose use must be limited. Because, these tools can be addictive which will affect the body's system (Nizar et. Al., 2017). However, the use of devices among school children has positive and negative impacts. Following is a description of the impact of the use of devices on school children by using a SWOT analysis.

\subsection{Strength}

In some literature the positive impact of the use of devices can be seen in Andari's research (2013) the positive impact of devices on children's development, including children getting ease of information and ease of establishing communication with long distances, the device is not only for communication, but can also be used as a means for entertainment. In 
addition, with technological advances in the internet world, children can get to know and establish communication with many people from various parts of the world; and as a result of technological advancements, many creative and challenging games are loved by children.

Not only that, the positive impact of the device on the child is also able to solve problems and facilitate communication, the child's logic develops, fine motor skills develop, visual spatial abilities develop, release tension, the ability to hear better, the child becomes independent and imaginative. Meanwhile, the negative impact is very influential on health, intellectual, social, physical, and psychological (Fahrurozi and Sutrisno, 2018).

In addition, interesting findings from Chalim and Anwas's research (2018), showed that the high number of students using the internet for the purpose of finding resources or learning materials, amounted to $72.2 \%$. The results of interviews with several students stated they were accustomed to finding learning materials from the internet. They also understand a number of search engines that are often used to find school subject matter. Respondents have the awareness and understanding that the internet is not just for entertainment and communication, but can be used to improve learning achievement (Anwas, 2016). The internet has been used for learning well. Whereas in many previous studies that the use of the internet through various devices, dominantly used for entertainment and communication purposes only (TechinAsia, 2015).

\subsection{Weakness}

The weaknesses or negative effects of using a device is easy to be hypnotized so that not a few children who use a device like the virtual world (playing devices) and forget the real world (playing with friends). This also happens to early childhood, including children becoming lazy writing and reading; because the device provides many conveniences, not a few children who are impatient in dealing with slowness and difficulties in everyday life; and a decrease in social skills (Andari, 2013)

In addition, Priyatna (2012) revealed a number of other negative impacts, namely children who are accustomed to playing games for more than 1 hour per day or an average of 7-10 hours per week, perhaps they will sacrifice their time to do homework and time to study which results negative for his academic achievement in school. Then the child becomes lazy to do physical activities that impact on children's health. If the child continues to stare at the screen on the device, it can cause vision problems. Too much sitting when playing a device can also cause problems in the bones, joints and muscles. Even lack of physical activity can also increase the risk of being overweight or obese. This is in line with findings (Prianggoro \& Hasto, 2014), Manumpil, et al (2015), Kezia Oroh, et al (2016), and Chalim and Anwas (2018) who revealed that excessive use of devices can have a negative impact on health, such as dry eyes, sleep disorders, neck pain, and obesity due to lack of exercise.

Another weakness of the use of devices is the impact of social media applications used by children. This is due to one of the serious problems faced by adolescents who incidentally are school children is cyber abuse or cyberbullying. Cyber harassment is one of the negative impacts of internet use. Cyber harassment is oppression through social media. At present, there are many cases of abuse that occur in adolescents. The Ministry of Communication and Information in collaboration with UNICEF in 2011 to 2013, which was released in February 2014, stated that most teenagers in Indonesia have been victims of cyberbullying. This study involved 400 children and adolescents aged 10 to 19 years. The study also revealed that nine out of ten students or $89 \%$ of respondents communicate online with their friends, $56 \%$ communicate online with family, and 35\% communicate online with their 
teacher. As many as $13 \%$ of respondents claimed to be victims of cyberbullying with forms of insults and threats (Rifauddin, 2016). Sartana \& Afriyeni (2017) research results also show that out of 353 respondents 275 respondents (78\%) claimed to have seen cyberbullying, 76 respondents $(21 \%)$ had been perpetrators, and 172 respondents $(49 \%)$ had been victims. Perpetrators are mostly done by using written media, sound, and images.

\subsection{Opportunity}

In addition to positive and negative impacts, the use of devices for school children also has opportunities that can be exploited. Aberg et al (2016) found that using digital learning resources can improve students' writing abilities. In addition, the results of the study of John et al (2016) also showed that online learning can increase the interaction and involvement of students.

Efforts to habituate the use of devices for learning purposes, apparently have an impact on learning resources that are often used by students. This is evident in the research conducted by Chalim and Anwas (2018) which explains the change in the use of learning resources in contemporary generation which is often referred to as digital native generation. If in the previous generation, the main learning source is books (conventional printed books). As the main source of learning, at that time the book was dubbed as a storehouse of knowledge. However, the present generation of Chalim and Anwas's research (2018) explains that almost all students when working on school assignments using the internet are mediated by devices. This is a demand of changing times. Currently some books have also been made digital versions.

Another opportunity in the use of devices by school children is through the provision of learning tasks that utilize the internet, apparently has a positive contribution to student achievement. Susena and Amelia (2014) research results conducted on high school students showed that after respondents were advised to search for subject matter via the internet the value was better than before being advised to search for subject matter on the internet. Schools that utilize the internet network to support learning have a higher value than schools that have not used the internet as learning support.

The internet is one type of media from many types of media. Like only books, on the internet there are many messages of education and learning. Students who often read textbooks to study, the internet presence is also used for learning purposes. This is in line with Chalim and Anwas's research (2018) which shows that the intensity of students in reading textbooks is significantly and positively related to the use of the internet as learning material. This means that students who are diligent in reading books to learn have a tendency to use the internet for learning. Even with the sophistication of the internet is more interesting than books because it can display learning messages in multimedia. Message learning in the internet is not only text-based but also based on audio, video, anmiasi, and even simulation (Anwas, 2016).

\subsection{Threat}

However, one thing that is unfortunate is the use of devices is still very small used for learning purposes. The results of a study conducted by TechinAsia (2015) showed that internet users in Indonesia were dominant in finding news and entertainment, even for educational content only $5 \%$. This is a threat to the use of devices by school children. In the study of Chalim and Anwas (2018) showed that the intensity of playing games via the internet, the intensity of the use of social media, and the intensity of using the internet were not significantly related to the intensity of using the internet for learning. Although in the 
findings it is known that the intensity of the use of social media such as: Facebook, WhatsApp, Twitter, and the like is quite high at $74 \%$, but it is not significantly related to the use of the internet for learning. The intensity of playing games is also high at $65.7 \%$, but it is also not significantly related to the use of the internet for learning. Likewise, the findings of the study showed that the intensity of the internet usage of each student was quite high at an average of over two hours per day, but apparently did not have a significant relationship with the use of the internet for learning. This implies, the intensity of the use of social media, playing online games, as well as the intensity of other internet use on students needs to be reduced because it turns out that it is not significantly related to the use of the internet for learning.

The same thing in the 2017 Sarbani and Subandoro research found that the majority of respondents, this native digital generation still utilizes Information Technology for fun and playing (communicating [85\%], playing games [62\%], editing and sending photos / videos [50\%], checking and writing status [48\%], watching film / music [43\%] Research respondents apparently have not been able to optimize the use of digital technology to support the success of their studies.

\section{Conclusion and Recommendations}

The use of gadgets among school children not only has positive and negative impacts, but also has opportunities as well as threats that are worth watching out for. Devices that are used incorrectly or excessively without supervision from parents, especially children as a user of the device can have a negative effect on the psychological impact of the child being private, disturbed sleep patterns, likes to be alone and on the child's development into obesity, exposure to radiation and eye health, hands, brain disturbed. However, the device can also be a means in the process of learning in children if it can be maximized properly utilized.

The digital revolution that uses devices has changed the culture of communication and people's behavior to move to media that is fast and easy. In many developed countries, gadgets have become an integral part of learning systems, information sources, learning based on electronic technology (e-learning), including e-libraries (digitally cataloged), selfdevelopment tools, means of socializing with friends online, across borders so that expanding friendships, building creativity, and encouraging economic growth. This is important so that the use of devices by children can be used for learning systems.

\section{References}

Aberg ES, Stahle Y, Engdahl I, Nyqvist HK. 2016. Designing a Website to Support Students Academic Writing Process. TOJET: The Turkish Online Journal of Educational Technology, 15(1): 33-42.

Afandi, R. (2011). Integrasi Pendidikan Karakter dalam Pembelajaran IPS di Sekolah Dasar.PEDAGOGIA: Jurnal Pendidikan, 1(1), 85-98.

Akmala, Said 2018. Perkembangan Internet Pada Generasi Muda Di Indonesia Dengan Kaitan Undang-Undang ITE Yang Berlaku. Cyber Security and Forensik Digital Journal, Vol 1, No 2

Al-Dheleal, Yahya M, Zaidatun T. 2017. Using Facebook for the Purpose of Students' Interaction and its Correlation with Students' Academic Performance. TOJET: The Turkish Online Journal of Educational Technology, 16(4) : 170-178. [Internet] dapat diunduh di http://www.tojet.net/articles/v16i4/16416.pdf. 
American School Counselor Association. (2011). The ASCA National Model: A Frame work For School Counseling Program Third Edition. Alexandria, VA: ASCA

Ananditha, A. C. (2017). Faktor-Faktor Yang Berhubungan Dengan Perkembangan Motorik Kasar Pada Anak Toddler. Jurnal Keperawatan Muhammadiyah, 2(1).

Andari. (2013). Dampak gadget pada Perkembangan Anak. [online]. Tersedia di: http://Kumpulan-Tulisan-DAMPAK-GADGET-PADA-PERKEMBANGANANAK.htm. Diakses 21 Maret 2019. [2] M.J. Benner, and M. L. Tushman, "Exploitation, exploration, and process management: the productivity dilemma revisited", Academy of Management Review vol. 28, no. 2, pp. 238-256, 2003.

Anies. 2005. Electrical Sensitivity Gangguan Kesehatan Akibat Radiasi Elektromagnetik. Jakarta: PT Elex Media Komputindo.

Anwas OM. 2011. Pembudayaan Teknologi Informasi dan Komunikasi di Sekolah. Jurnal Teknodik, Pustekkom Kemendikbud, XV(1) : 75-83.

Anwas OM. 2016. Model Buku Teks Pelajaran berbasis Teknologi Informasi dan Komunikasi. Jurnal Kwangsan BPMTP Surabaya, 4(1) : 17-32.

Armstong. (2003). Smart Baby's Brain: Merangsang Kejeniusan Anak di Tiga Tahun Pertama. Jakarta: Prestasi Pustaka

Barak, A. (2008). Psychological Aspects of Cyberspace: Theory, Research, Applications. New York: Cambridge University Press.

Bawelle. 2016. "Hubungan Penggunaan Smartphone Dengan Fungsi Penglihatan Pada Mahasiswa Fakultas Kedokteran Universitas Sam Ratulangi Manado Angkatan 2016." Jurnale-Biomedik (eBm) 4.

Bhakti, C.P. \& Nindiya, E.S. (2017). Peran Bimbingan dan Konseling untuk Menghadapi Generasi Z Dalam Perspektif Bimbingan dan Konseling Perkembangan. Jurnal Konseling GUSJIGANG. Vol. 3 (1).

Bhakti, CP, Hasan SUN. et.al. (2015). Peran layanan bimbingan dan konseling komprehensif dalam pengembangan karakter cerdas anak sekolah dasar. Jurnal Konseling Komprehensif. Vol 2 (2) : 203-211.

Caraka Putra Bhakti, Nindiya Eka Safitri, Anne Cyntia Dewi, (2018) Strategi Layanan Bimbingan dan Konseling untuk Mengurangi Perundungan Siber di Kalangan Remaja, Jurnal Psikoedukasi dan Konseling Vol 2, No. 2, Desember 2018

Chalim, Saifuddin, Anwas, E. Oos M., (2018) Peran Orangtua dan Guru dalam Membangun Internet sebagai Sumber Pembelajaran, Jurnal Penyuluhan, Maret 2018 Vol. 14 No. 1

Chusna, Puji Asmaul. 2017. "Pengaruh Media Gadget Pada Perkembangan Karakter Anak." JURNAL DINAMIKA PENELITIAN 17.

Dasli APE, Muljono P, Susanto J. 2015. Pemanfaatan Cyber Extension melalui Telepon Genggam oleh Petani Anggrek di Taman Anggrek Ragunan Jakarta Selatan. Bogor (ID): Jurnal Penyuluhan, 11(2) : $1-10$.

Dinatha, N. M. (2017). Pemanfaatan Media Sosial Facebook untuk Menilai Sikap Ilmiah (Afektif) Mahasiswa. Journal of Education Technology, 1(No. (3)), 211-217.

Fahriantini E. 2016. Peranan Orangtua dalam Pengawasan Anak pada Penggunaan Blackberry Messenger di Al Azhar Syifa Budi Samarinda. eJournal Ilmu Komunikasi, 2016: 4(4): 44-55.

Fahrurrozi, Sutrisno (2018) Pendampingan Orang Tua Dalam Menghadapi Era Digital Bagi Siswa Sekolah Dasar, Jurnal Pemberdayaan Sekolah Dasar (JPSD) - Vol. 1 No. 1 Oktober 2018

Faisal N. 2016. Pola Asuh Orang Tua dalam Mendidik Anak di Era Digital. Jurnal An-Nisa, IX(2) : 121-137. 
Fitri S. 2017. Dampak Positif dan Negatif Sosial Media terhadap Perubahan Sosial Anak. Naturalistic: Jurnal Kajian Penelitian Pendidikan dan Pembelajaran 1(2) : 118-123.

Kezia Oroh, dkk. 2016. Gambaran Penggunaan Ponsel Pintar Sebagai Faktor Risiko Nyeri Kepala Primer Pada Mahasiswa Angkatan 2013 Fakultas Kedokteran Universitas Sam Ratulangi Manado. Jurnal e-Clinic (eCl). 4(2) : 1-6. (Online).https://ejournal.unsrat.ac.id/index.php/eclinic/article/viewFile/14486/14059

(Diakses Pada 27 Februari 2018)

Manumpil, dkk. (2015). Hubungan Penggunaan Gadget dengan Tingkat Prestasi Siswa di SMA Negeri 9 Manado. Jurnal ejoural Keperawatan (e-Kep). Volume 3 Nomor 2 Tahun 2015, 1-5.

Maya, N. (2015). Fenomena Cyberbullying Di Kalangan Pelajar. Jurnal ilmu sosial dan politik, Vol. 4 (3).

Mubashiroh. (2013). Gadget, penggunaan dan dampak pada anak-anak. Semarang: Universitas Negeri Semarang.

Muna, R. F., \& Astuti, T. P. (2014). Hubungan antara Kontrol Diri dengan Kecenderungan Kecanduan Media Sosial pada remaja Akhir. Empati, 3(4), 481-491.

Nizar Rabbi Radliya, Seni Apriliya, Tria Ramdhaniyah Zakiyyah, (2017) Pengaruh Penggunaan Gawai Terhadap Perkembangan Sosial Emosional Anak Usia Dini, Jurnal PAUD Agapedia, Vol.1 No. 1 Juni 2017, page 1-12

Nugraha, A. \& Rachmawati, Y. (2008). Metode Pengembangan Sosial Emosional. Jakarta: Penerbit Universitas Terbuka.

Nurjanah, S. (2014). Pengaruh Penggunaan Media Sosial Facebook Terhadap Perilaku Cyberbullying Pada Siswa SMAN 12 Pekanbaru. Jom FISIP, 1 (2): 2.

Prensky, Marc. 2001. Digital Natives, Digital Immigrant. Journal From on the Horizon. MCB University Press, Vol. 9 No. 5, October 2001.

Priyatna, A. (2012). Parenting di Dunia Digital. Jakarta: PT. Elex Media Komputindo.

Rifauddin, M. (2016). Fenomena Cyberbullying Pada Remaja (Studi Analisis Media Sosial Facebook). Jurnal Ilmu Perpustakaan, Informasi, dan Kearsipan Khizanah AlHikmah,. $\quad$ Vol. $4 \quad$ (1), http://journal.uinalauddin.ac.id/khizanah-alhikmah/article/download/1068/pdf

S.P.Hariningsih. 2005. Teknologi Informasi. Penerbit Graha Ilmu. Yogyakarta.

Sartana \& Afriyeni. (2017). Perilaku Perundungan maya (Cyberbullying) Pada Remaja Awal. Jurnal Psikologi Insight, Vol. 1, No. 1, April 2017: hlm 25-41

Sujarwo. 2011. Motivasi Berprestasi Sebagai Salah Satu Perhatian dalam Memilih Strategi Pembelajaran. https://journal.uny.ac.id/index.php/mip/article/download/ 6858/5891. (diakses pada 23 Maret 2017).

Sukirman, (2017) Integrasi Pendidikan Karakter Pada Pembelajaran Berbasisi Game Untuk Mengajarkan Perilaku Santun di Media Sosial, Jurnal Pendidikan Ilmu Sosial, Vol 27, No.2, Desember 2017

Supriatna, M. (2011). Bimbingan dan Konseling Berbasis Kompetensi. Jakarta: PT Rajagrafindo Persada.

Susena E, dkk, Dewi A. 2014 Dampak Penggunaan Internet terhadap Kecerdasan Pelajar Sekolah Menengah Atas di Daerah Pedesaan dalam Rangka Peningkatan Kualitas Pendidikan di Daerah Pedesaan. Surakarta (ID): Jurnal Sainstech Politeknik Indonusa Surakarta, 1(2) : 1-10.

Ulinuhha M. 2013. Melindungi Anak dari Konten Negatif Internet; Studi terhadap Peramban Web Khususnya Anak. Jurnal Sawwa, 8(2) : 341-360. 
Widiartanto, Y. H. (2016, April 24). 2016, Pengguna Internet di Indonesia Capai 132 Juta. Kompas.com.

Wingkel, WS. 2007. Bimbingan dan Konseling di Instusi Pendidikan. Media Abadi. Yogyakarta.

Akhzalini, H. A. (2015). Inovasi Bimbingan dan Konseling dalam Mengurangi Traumatic Stress pada Korban Bullying di Sekolah. Prosiding Seminar Nasional Bimbingan dan Konseling Universitas Muhammadiyah Malang, ISBN: 978-979-796-149-7.

Broto, G. S. D. (2014). Riset Kominfo dan UNICEF Mengenai Perilaku Anak dan Remaja Dalam Menggunakan Internet. Jakarta.

Bhakti, CP., Safitri, NE., \& Fuad, A. R. (2016). Improving Quality of Education Through Collaboration System in The Perspective of Comprehensive Guidance and Counseling. International Conference Proceedings 2nd ICET: Improving The Quality of Education and Training Through Strengthening Networking. Faculty of Education, State University of Malang

Asosiasi Penyelenggara Jasa Internet Indonesia. (2016). Info Grafis Penetrasi \& Penggunaan Internet Indonesia Survey 2016. Retrieved From http://apjii.or.id/survei

Baskoro, R. (2014). Game Online Indonesia Tahun 2014 : Ikhtisar dan Infografis. Retrieved from https://www.duniaku.net/2015/02/20/game-online-indonesia-tahun-2014ikhtisardan-infografis/

Yunus, Ahmad. 2012. Cerdas Berinternet itu Sebuah Pilihan. http://internetcerdasindonesia.org/artikel-internet-cerdas/cerdas-berinternet-itusebuah-pilihan. (diakses 21 Maret 2019) 